\title{
SiM
}

\section{New Roles for Rangelands and Grasslands}

\section{The Cooperative State Research, Education and Extension Service (CSREES) is retooling its efforts to build awareness for rangeland and grassland attributes.}

\section{By Kindra Gordon}

1

s concerns about urbanization, rural economies, and clean air and water continue to challenge society in the future, rangelands and grasslands could play an important role in addressing those issues.

That's the thinking behind renewed efforts by the USDA Cooperative State Research, Education and Extension Service (CSREES) to develop a national program in rangelands and grasslands.

"America's increasing population requires land managers to view rangeland as a source of many benefits," says Jim Dobrowolski, who was named the National Program Leader for the CSREES effort last September. He points out that where-

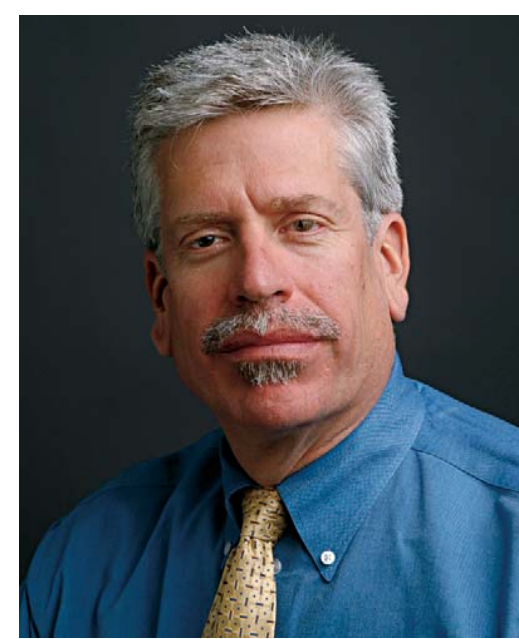

Jim Dobrowolski as rangelands and grasslands are important for productionbased outputs, such as energy, grazing, and minerals, they also need to be considered for offering aesthetics, wildlife habitat, and recreation.

He believes building awareness for rangelands and grasslands will help people recognize the ecosystem services these lands provide - such as helping maintain air and water quality, open space, and providing open lands around urbanization.

"Our goal is to design a program that meets the needs of society by integrating research, outreach and education programs, and enabling land managers to make appropriate decisions about the most effective uses of the land," says Dobrowolski.

Based in Washington, DC, Dobrowolski is helping coordinate the Rangelands and Grasslands program by developing partnerships with university, USDA, and other federal, state, and private entities to deliver research, education, and outreach efforts. He anticipates that the new program will help to promote a broader education of land managers and the public about the positive benefits of properly managed grazing lands as well as provide insight into rangeland watershed management and restoration efforts (see "Program under construction").

\section{Why Now?}

Dobrowolski reports that few new initiatives in rangeland and grassland research, education, and outreach were introduced over the past 15 years. "The timing was right, and the need was there to combine rangeland and grassland ecosystems into a single national program." With 22 years of experience in both the extension service and as a teaching/researching university professor, Dobrowolski was recruited from Washington State University to lead the new program. 


\section{Program under construction}

In developing CSREES's National Rangelands and Grasslands program, Jim Dobrowolski is holding listening sessions with researchers, educators, and stakeholder groups to gather input on the needs they've identified in the areas of rangelands and grasslands research, education, and outreach.

He cites some of the goals for the program as

- continuing to improve assessment procedures for rangeland and grassland health and status in ways that are faster, better, cheaper;

- continuing research efforts in ecology, physiology, and biotechnology of both plants and animals to aid in fire restoration and invasive weed control efforts, to help preserve biodiversity, to assist with sustainability, and to provide ecosystem services, such as water, habitat, and aesthetics;

- improving key sustainability factors that will ensure flexibility in addressing future demands for products and services;

- identifying employment potential in rangeland and grassland careers and relaying that information to universities and students.

If you'd like to visit with Dobrowolski about the CSREES Rangelands and Grassland Ecosystems program, contact him at (202) 401-5016 or jdobrowolski@csrees.usda. gov.

With the growing concern about weeds, fire, fragmentation, drought, watershed management, and sustainability, among the many issues challenging today's land managers, Dobrowolski believes the renewed interest in developing the program could have much to offer.

Through a 3-pronged approach focusing on rangeland and grassland research, education, and outreach, Dobrowolski believes possible outcomes may include

- improved public perceptions about the value of rangeland and grassland ecosystems and the people who manage them;

- slowed weedy invasions and improved production and biodiversity;

- sustainable rangelands and grasslands both kept as large unbroken landscapes and smaller sustainable parcels linked by riparian and other corridors;

- maintaining appropriate fire cycles and ecological status;

- and thriving human communities.

As an example of such outcomes, Dobrowolski shares that 2 national Conservation Effects Assessment Project watersheds, including 1 related to the drinking water supply for
Wichita, Kansas, cite proper management-intensive grazing practices that help enhance watershed quality. Through the national Rangelands and Grasslands program, more strides could be made in research for similar projects as well as providing technical assistance to landowners to implement new science-based technologies.

Dobrowolski is hopeful the program will also help identify the critical issues that rangeland managers and scientists need to be trained in for the future, so university curricula can be adapted to meet those needs. For instance, the increasing trend for people to own small acreages or ranchettes presents unique land issues that future land managers need to be able to address.

Additionally, Dobrowolski believes that the program may be beneficial in identifying strategies to landowners that can boost rural economies. For example, value-added income streams may include water leasing, grass banks, supplying native seed, fee hunting, and/or paid nature and agritourism experiences.

\section{Linking Land and People}

Dobrowolski says another important area in which the CSREES Rangelands and Grasslands program can have an important impact is in connecting people - especially youth-to the land.

He points out that fewer young people have the opportunity to grow up with exposure to agriculture and nature-which is leading to a new challenge in today's society referred to as "Nature Deficit Disorder" (NDD). That term was coined by author Richard Louv in his book Last Child in the Woods: Saving Our Children from Nature Deficit Disorder, in which he argues that kids are so plugged into television and video games that they've lost their connection to the natural world.

Dobrowolski points out that this disconnect could create a risk to agricultural and rural economies in the future. He says, "When youth don't have a grasp of the importance of agriculture and natural resources and what rangeland and grassland ecosystems can provide, the result is that as adults they aren't concerned with issues like maintaining land from being fragmented by urbanization."

He adds that NDD could produce a future generation that does not have the knowledge or understanding of dynamic environmental processes or that humans are an integral part of ecosystems. He is concerned that this growing disconnect with nature has serious implications for the future stewardship of our public lands and waters, which could endanger our country's conservation legacy.

Dobrowolski believes rangeland programs could help bridge the gap caused by that disconnect. He says, "We have kids in society who will never have the opportunity to be on a farm or ranch-unless they [farmers and ranchers] provide that to them. If they have experiences with nature, they have a better chance of understanding the societal value that rangelands and grasslands provide." 


\section{Educational tools available}

The new CSREES Rangelands and Grasslands program leader is liaison to the Renewable Resources Extension Act (RREA)-funded web-based learning center at www.forestandrange.org. Coordinated by the University of Tennessee, with input from several other land-grant universities, the center offers educational opportunities for private forest and range landowners. It includes interactive learning modules that allow participants to improve their knowledge of natural resources.

Teachers interested in including rangeland and grassland principles in the classroom also have a new curriculum available that they can tap. The publication is called "At Home on the Range," and it is targeted toward 4- $\mathrm{H}$ and $\mathrm{K}-12$ youth. Initiated in 2005 by a group of individuals who convened at Montana State University representing Cooperative Extension, the Nature Conservancy, 4- $\mathrm{H}$, primary schools, universities, and others, "At Home on the Range" is the first national curriculum for rangeland that meets the National Science Education standards. To obtain information about this curriculum contact Kirk Astroth, Director, Montana 4-H Center for Youth Development, Montana State University, 210 Taylor Hall, Bozeman, MT 59717-3580.

As an added benefit, exposing youth to rangelands and grasslands may stimulate career choices in natural resource fields as well, says Dobrowolski (see "Educational tools available").

\section{Building Relationships}

As the CSREES Rangelands and Grasslands program is developed, Dobrowolski anticipates that new methods of pro- viding research and management knowledge to land managers and the public must also be developed.

"We need to be able to provide knowledge that people can use today to help their bottom line or their management planning without a tremendous amount of interpretation," he says.

He believes that means developing relationships with land managers that foster behavioral change. He says, "Often Extension folks get tapped to provide larger and larger workshops, reducing their ability to build trusting relationships that might eventually lead to adoption of new practices and behavior changes that make a real impact."

He points out that, in today's Web-based world, people can easily go to the Internet to find information. "We must develop new tools that combine current and future education technologies with a relationship of trust to help landowners sort through the information and make decisions for their operation."

To that end, Dobrowolski suggests educational materials of the future must be developed and delivered so they are user-friendly and available to youth-downloadable as podcasts, for example. He cites what he calls the four Rs for successful extension—Reliability, Relevancy, Response-time, and Research-based.

He adds that educators and rangeland managers also need training in social issues and working with people so they can facilitate relationship building and foster technology adoption and change.

Of the CSREES Rangelands and Grasslands program, he concludes by saying, "It's time for us to retool and see how we can be more effective."

Author is a freelance writer based near Sturgis, SD, and has been a member of the Society for Range Management since 1992, office@gordonresources.com. 